\title{
Article \\ High Temperature Alters Secondary Metabolites and Photosynthetic Efficiency in Heracleum sosnowskyi
}

\author{
Anna Rysiak ${ }^{1, *}$, Sławomir Dresler ${ }^{2, *}\left(\mathbb{D}\right.$, Agnieszka Hanaka $\left.{ }^{3}{ }^{(}\right)$, Barbara Hawrylak-Nowak ${ }^{4}(\mathbb{D}$, \\ Maciej Strzemski $^{2}{ }^{\mathbb{D}}$, Jozef Kováčik ${ }^{5}$, Ireneusz Sowa ${ }^{2} \mathbb{D}$, Michał Latalski ${ }^{6} \mathbb{D}$ and Magdalena Wójciak ${ }^{2} \mathbb{C}$ \\ 1 Department of Botany, Mycology and Ecology, Institute of Biological Sciences, Maria Curie-Skłodowska \\ University, Akademicka 19, 20-033 Lublin, Poland \\ 2 Department of Analytical Chemistry, Medical University of Lublin, Chodźki 4a, 20-093 Lublin, Poland; \\ maciejstrzemski@umlub.pl (M.S.); i.sowa@umlub.pl (I.S.); magdalenawojciak@umlub.pl (M.W.) \\ 3 Department of Plant Physiology and Biophysics, Institute of Biological Sciences, Maria Curie-Skłodowska \\ University, Akademicka 19, 20-033 Lublin, Poland; agnieszka.hanaka@poczta.umcs.lublin.pl \\ 4 Department of Botany and Plant Physiology, University of Life Sciences in Lublin, Akademicka 15, \\ 20-950 Lublin, Poland; barbara.nowak@up.lublin.pl \\ 5 Department of Biology, University of Trnava, Priemyselná 4, 91843 Trnava, Slovakia; jozkovacik@yahoo.com \\ 6 Children's Orthopedics Department, Medical University of Lublin, Gębali 6, 20-093 Lublin, Poland; \\ michallatalski@umlub.pl \\ * Correspondence: anrysiak@poczta.umcs.lublin.pl (A.R.); slawomir.dresler@umlub.pl (S.D.); \\ Tel.: +48-81-537-50-14 (A.R.); +48-81-448-7180 (S.D.)
}

check for updates

Citation: Rysiak, A.; Dresler, S.; Hanaka, A.; Hawrylak-Nowak, B.; Strzemski, M.; Kováčik, J.; Sowa, I.; Latalski, M.; Wójciak, M. High Temperature Alters Secondary Metabolites and Photosynthetic Efficiency in Heracleum sosnowskyi. Int. J. Mol. Sci. 2021, 22, 4756. https:/ /doi.org/10.3390/ijms22094756

Academic Editor: Marcello Iriti

Received: 29 March 2021

Accepted: 28 April 2021

Published: 30 April 2021

Publisher's Note: MDPI stays neutral with regard to jurisdictional claims in published maps and institutional affiliations.

Copyright: (c) 2021 by the authors. Licensee MDPI, Basel, Switzerland. This article is an open access article distributed under the terms and conditions of the Creative Commons Attribution (CC BY) license (https:// creativecommons.org/licenses/by/ $4.0 /)$.

\begin{abstract}
Due to global warming, invasive species have spread across the world. We therefore studied the impact of short-term ( 1 day or 2 days) and longer (7 days) heat stress on photosynthesis and secondary metabolites in Heracleum sosnowskyi, one of the important invasive species in the European Union. H. sosnowskyi leaves exposed to short-term heat stress $\left(35^{\circ} \mathrm{C} / 1 \mathrm{~d}\right)$ showed a decrease in chlorophyll and maximum potential quantum efficiency of photosystem II (Fv/Fm) compared to control, $35^{\circ} \mathrm{C} / 2 \mathrm{~d}$, or $30^{\circ} \mathrm{C} / 7 \mathrm{~d}$ treatments. In turn, the high level of lipid peroxidation and increased $\mathrm{H}_{2} \mathrm{O}_{2}$ accumulation indicated that the $30^{\circ} \mathrm{C} / 7 \mathrm{~d}$ stress induced oxidative damage. The contents of xanthotoxin and bergapten were elevated in the $2 \mathrm{~d}$ and $7 \mathrm{~d}$ treatments, while isopimpinellin was detected only in the heat-stressed plants. Additionally, the levels of free proline and anthocyanins significantly increased in response to high temperature, with a substantially higher increase in the $7 \mathrm{~d}\left(30{ }^{\circ} \mathrm{C}\right)$ treatment. The results indicate that the accumulation of proline, anthocyanins, and furanocoumarins, but not of phenolic acids or flavonols, contributes to protection of $H$. sosnowskyi plants against heat stress. Further studies could focus on the suppression of these metabolites to suppress the spread of this invasive species.
\end{abstract}

Keywords: heat stress; invasive plants; furanocoumarins; phenolic metabolism; photosynthesis

\section{Introduction}

Two of the greatest threats to biodiversity and ecosystem functioning are species invasions and global climate change [1]. Furthermore, climate change and invasions may interact, with climate-change conditions favoring and, thus, facilitating the spread of non-native species [2]. The mechanism underlying the interaction between climate change and biological invasions, however, remains unclear. One of the fundamental questions in invasion ecology is the issue of what makes an invading species successful. In order for invaders to become established in a recipient environment, they must first pass through the "ecological filter" of the environment [3]. Temperature is often regarded as the most important abiotic factor in determining species distribution owing to its impact on biochemical and cellular processes, which, in turn, affect organismal performance [4,5].

In particular, given the climate warming and prediction of global warming of 1.5 to $2.0{ }^{\circ} \mathrm{C}$ by 2050 [6], heat stress is currently considered one of the important factors that 
directly influence plant growth and development [7]. Exposure of plants to heat affects many aspects of vegetative processes-growth, yield, and generative development [8]. High temperature leads to many physiological and biochemical changes. Several effects of higher temperatures have been identified, including reduction of growth, alteration in photosynthesis, inhibition of seed germination, improper development, alteration in secondary metabolism $[9,10]$, and overproduction of reactive oxygen species (ROS) resulting in oxidative stress [8].

Heracleum sosnowskyi Manden. (Apiaceae) belongs to the group of "large" or "giant" hogweeds and is listed as an invasive species in the European Union. H. sosnowskyi spread rapidly in Poland, the Baltic States, and Russia after its introduction as a fodder plant. It is an undesirable invader due to its large size, high seed production, and vigorous growth, leading to gross changes in vegetation and obstruction of access to riverbanks. The health hazards of this species via serious dermatological effects on skin contact are the main reasons for concern over its spread [11]. Here we studied temperature stress tolerance as a potential contributor to the success of $H$. sosnowskyi and examined the role of SMs and photosynthetic efficiency. In particular, the objectives of this study were to (i) investigate the sensitivity of $H$. sosnowskyi to acute heat stress versus moderate long-term high temperature in relation to oxidative stress markers and photosynthesis efficiency and (ii) evaluate and estimate polyphenolic compounds, especially furanocoumarin levels in the plants under heat stress.

\section{Results and Discussion}

\subsection{Impact of Heat Stress on Pigments Content and Parameters of Chlorophyll a Fluorescence}

Among photosynthetic pigments, chlorophyll $a$ (chl $a$ ), chlorophyll $b(\mathrm{chl} b)$, and carotenoids (car) were measured. To evaluate the chlorophyll $a$ fluorescence, the following parameters were established: minimal fluorescence in the dark-adapted state (F0), maximal fluorescence in the dark-adapted state (Fm), maximum quantum yield of PSII in the darkadapted state $(\mathrm{Fv} / \mathrm{Fm})$, photochemical quenching $(\mathrm{qP})$, nonphotochemical quenching of fluorescence (qN), and the ratio of fluorescence decrease (Rfd).

Under the shortest temperature stress $(1 \mathrm{~d})$, the decrease in the content of all photosynthetic pigments was significant (Figure 1a). Under longer exposure $(\geq 2 \mathrm{~d})$, both chlorophyll forms and carotenoids had a clear tendency to elevate above the level achieved at the shortest time of stress exposure. In agreement with our results, there is evidence that thermal stress can reduce the total chlorophyll content, e.g., in Cucumis sativus [12] or Artemisia sieberi alba [13], the chl $a$ content in soybean [8], and the chl $b$ content in Valerianella locusta [14]. Moreover, under high temperature, the denaturation or inhibition of enzymes involved in chl biosynthesis results in the depleted concentration of these pigments [15]. However, the results indicated that increasing pigment content under longer exposure in comparison to the $1 \mathrm{~d}$ treatment may contribute to the acclimatization of plants.

Photosynthesis is one of the most heat-sensitive physiological processes [8]. Measurement of chl $a$ fluorescence is frequently used in order to assess high-temperature-induced changes in the thylakoid membranes and, as a consequence, PSII damage [16-18]. Moreover, among all parameters of chl a fluorescence, $\mathrm{Fv} / \mathrm{Fm}$ and F0 seem to be good indicators of the function of PSII reaction centers under the temperature exceeding heat tolerance limit $[16,18]$. Though some studies considered PSII as a strongly temperature-sensitive constituent of the photosynthetic apparatus $[19,20]$ leading to decreased thylakoid membrane stacking, increased fluidity, reorganization of the membranes $[18,21,22]$, and the relocation of PSII light-harvesting complexes from the thylakoid membrane [23], other studies did not provide the same outcomes. PSII cannot be always significantly affected at $35-45{ }^{\circ} \mathrm{C}$ [17], which is in agreement with the results of our study. By application of the fluorescence parameters, we proved that plants demonstrated the ability to recover from the temperature stress within a short period ( $2 \mathrm{~d}$ or longer). It can be the evidence for efficiently working machinery for protein biosynthesis in order to protect and repair any thermal damage of PSII and to maintain the balance between oxidants and antioxidants $[18,24,25]$ or resistance 
against irreversible heat-induced structural changes [17]. Furthermore, the alterations in the levels of lipid desaturation in thylakoid membranes can be associated with the level of thermosensitivity of PSII [26].

The values of two parameters of chlorophyll $a$ fluorescence, Fv/Fm and Rfd, are presented in Figure 1b,c and in Supplementary Materials Figure S1. A temporal decrease in $\mathrm{Fv} / \mathrm{Fm}$ under short-term stress with subsequent recovery to the control level under long-term exposure was detected (Figure 1b). Initially, a decrease in the Fv /Fm values indicated a reduction in PSII efficiency, mainly by photoinhibition [27], as reported, e.g., in short-term heat-stressed potato [28]. Then, under the prolonged action of adverse temperature, the plant showed strong resistance to photoinhibition, reaching the same level of Fv /Fm under the long-term exposure as the control plants. Similarly, in our previous study [14] with Valerianella locusta exposed to long stress, the Fv / Fm ratio was stable and unaffected by the temperature. On the other hand, the Rfd index decreased regardless of the level and duration of the applied temperature stress (Figure 1c). This parameter seems to be more sensitive to the high temperature, which can be explained by the lower rate of photosynthetic $\mathrm{CO}_{2}$ assimilation under such conditions [29].
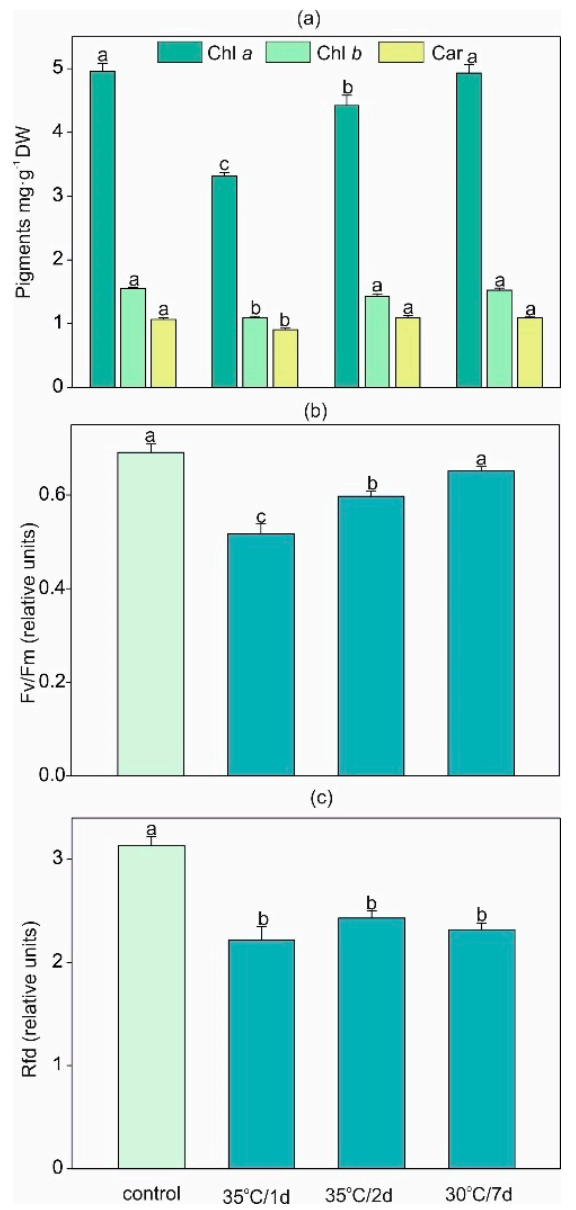

Figure 1. Photosynthetic pigment content: (a) chlorophyll $a, b$ and carotenoids and chlorophyll fluorescence parameters: (b) Fv / Fm-maximum quantum yield of PSII/maximal fluorescence in the dark-adapted state, respectively; (c) Rfd-ratio of fluorescence decrease in H. sosnowskyi exposed to heat stress. Data are means \pm SE ( $n=4$ for pigments, $n=8$ for fluorescence parameters). Values followed by the same letter(s) are not significantly different according to Tukey's test $(p<0.05)$.

Both F0 and Fm showed an increase only after $1 \mathrm{~d}$ of heat stress with recovery to the control level under longer exposure (Supplementary Materials Figure S2a,b). F0 is a convenient parameter for monitoring the high-temperature impact on PSII inactivation [16]. An 
increase in the F0 value is observable under various stresses, such as water deficiency [30] or salt stress [31]. In the present study, the reversible increase in F0 (under $35^{\circ} \mathrm{C} / 1 \mathrm{~d}$ treatment) could be caused by the temporal inactivation of the PSII reaction center [32] or by the reduction of the primary plastoquinone $(\mathrm{PQ})$ acceptors $\left(\mathrm{Q}_{\mathrm{A}}\right)$ through $\mathrm{PQ}$ in the dark [16] with the subsequent recovery of the inhibition just after $2 \mathrm{~d}$. The reason for the F0 increase is species dependent [16]. Moreover, the temporal elevation in the F0 value was not associated with the reduction in Fm as it was presented in other studies [33], thus no impairment of the light-harvesting complex of PSII can be suggested. Additionally, an increase in F0 after $1 \mathrm{~d}$ of heat stress was connected with the decline in Fv/Fm, which is in accordance with other results [34].

The qN shows the part of absorbed radiation that is not used for electron transport in photosynthesis, and besides the conversion of violaxanthin to zeaxanthin in the xanthophyll cycle, the photosystem II subunit $S$ protein (PsbS) protein is also involved in this process [35]. This parameter increased significantly under the $1 \mathrm{~d}$ and $2 \mathrm{~d}$ stress but decreased under the $7 \mathrm{~d}$ exposure (Supplementary Materials Figure S2c). This provides evidence for the acidification of the thylakoid lumen due to the accumulation of protons and, in consequence, to the transitional, short-lasting increase in $\mathrm{qN}$ [25]. In agreement with our data, $3 \mathrm{~d}$ of heat treatment (but not $6 \mathrm{~h}$ of heat) increased $\mathrm{qN}$ in potatoes [28]. The $\mathrm{qP}$ indicates the proportion of open PSII reaction centers [36]. The value of qP was reduced under shorter heat exposure ( $1 \mathrm{~d}$ and $2 \mathrm{~d}$ ) and recovered to the control level in the long-term temperature conditions (Supplementary Materials Figure S2d).

The difference in the effects on some fluorescence parameters mentioned in the literature is strongly dependent on the strength and length of the temperature stress chosen for the particular species [16,23], e.g., St. John's wort [9] or Cucumis sativus [12]. We proved that high temperature influencing the content of photosynthetic pigments and chl $a$ fluorescence can have an effect on the thylakoid membrane with PSII photochemistry, which is in agreement with other findings $[7,23]$.

\subsection{High-Temperature-Induced Changes in Lipid Peroxidation and the $\mathrm{H}_{2} \mathrm{O}_{2}$ and Proline Content}

Heat stress in plants is a complex function of the magnitude, duration, and rate of temperature rise, which can lead to irreversible damage to plant metabolism [7]. One of the first heat stress symptoms is the overproduction of reactive oxygen species (ROS), which induces the peroxidation of membrane lipids [37]. Here we found that both acute heat stress and longer stress induced $\mathrm{H}_{2} \mathrm{O}_{2}$ accumulation. As shown by the $\mathrm{H}_{2} \mathrm{O}_{2}$ visualization, the accumulation of $\mathrm{H}_{2} \mathrm{O}_{2}$ increased in the order: control $<35^{\circ} \mathrm{C} / 1 \mathrm{~d}<35{ }^{\circ} \mathrm{C} / 2 \mathrm{~d}<30{ }^{\circ} \mathrm{C} / 7 \mathrm{~d}$ (Figure 2). A similar increase in the content of thiobarbituric-acid-reactive substances (TBARS) stimulated by high temperature, i.e., by a ca. 4-, 5-, and 7-fold increase for $35^{\circ} \mathrm{C} / 1 \mathrm{~d}, 35^{\circ} \mathrm{C} / 2 \mathrm{~d}$, and $30^{\circ} \mathrm{C} / 7 \mathrm{~d}$, respectively, was observed (in comparison with control, Figure 3a).

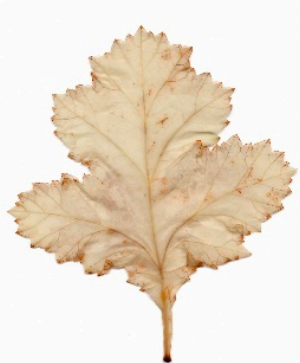

Control

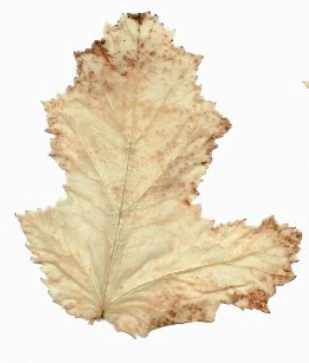

$35^{\circ} \mathrm{C} / 1 \mathrm{~d}$

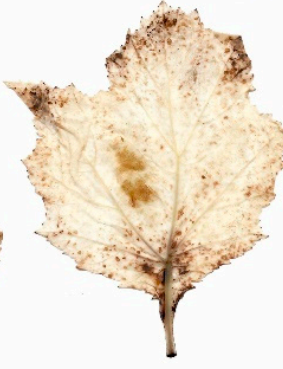

$35^{\circ} \mathrm{C} / 2 \mathrm{~d}$

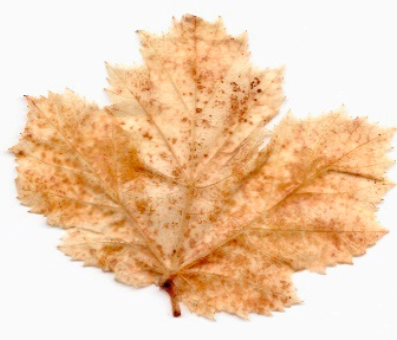

$30^{\circ} \mathrm{C} / 7 \mathrm{~d}$

Figure 2. Histochemical detection of $\mathrm{H}_{2} \mathrm{O}_{2}$ using DAB staining in the leaves grown under several thermal conditions. The intense brown color indicates the accumulation of $\mathrm{H}_{2} \mathrm{O}_{2}$. 

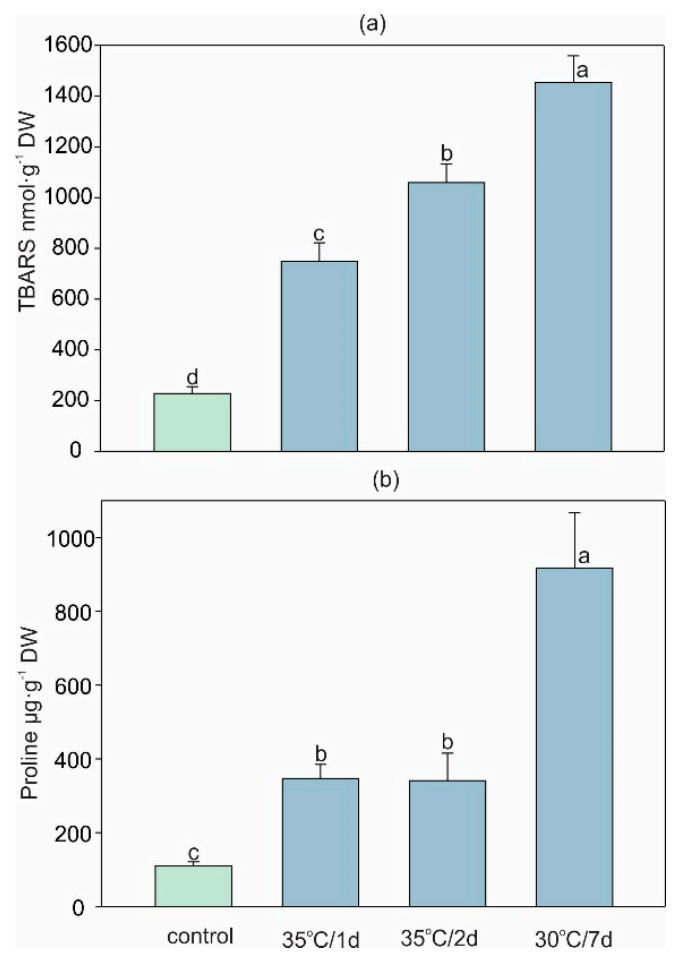

Figure 3. Changes in (a) the level of lipid peroxidation expressed by the thiobarbituric-acid-reactive substances (TBARS) content and (b) free proline content in leaves of H. sosnovskyi in response to heat stress. Data are means \pm SE $(n=4)$. Values followed by the same letter(s) are not significantly different according to Tukey's test $(p<0.05)$.

The accumulation of TBARS is a common indicator of ROS-induced damage to cell membranes as an indicator of oxidative stress processes [14]. High temperature stress has been found to induce membrane lipid peroxidation in many plant species [37,38], and the level of lipid peroxidation is correlated with the duration of heat stress [39]. However, it should be noted that the rate of lipid peroxidation may vary. Jiang and Huang [39] described lipid peroxidation beginning after 18 days of heat stress treatment of two grass species, but cell membrane damage was also observed after one day of heat treatment [40].

The common plant response to heat stress involves an accumulation of osmolytes such as proline $[7,15]$. The short-term acute stress in both variants caused an approx. 3 -fold increase in its content, while an 8.4-fold higher amount of proline compared to the control was found under longer $/ 7 \mathrm{~d}$ treatment (Figure $3 \mathrm{~b}$ ). Although some evidence has indicated that the overaccumulation of proline can be toxic to plants [41], this compound can also be responsible for stabilization of the structure of proteins, cell membrane protection, and ROS scavenging [42]. Additionally, proline plays a crucial role in maintaining water status in stressed plants [39]. Our study showed, surprisingly, that both the $30{ }^{\circ} \mathrm{C} / 7 \mathrm{~d}$ and $35^{\circ} \mathrm{C} / 2 \mathrm{~d}$ stress did not decrease the percentage content of water but even slightly elevated it (Supplementary Materials Figure S3). Although the present results are in contrast with previous studies [14,15], which showed a decrease in the water content in heat-stressed plants, we can suppose that the high accumulation of osmolytes and the higher flexibility of cell walls under heat stress [43] allowed the accumulation of higher amounts of water by leaves.

\subsection{Impact of High Temperature on SMs and Antioxidant Capacity}

Several studies have documented an increase in SMs or changes in the chemical profile within specimens of the same plant species growing under different biotic or abiotic stress factors $[44,45]$. There is evidence that high temperature stress exerts great effects on the production and accumulation of polyphenolic compounds [7]. It has been pointed out 
that the induction of phenolic biosynthesis in plants exposed to heat stress is one of the acclimatation processes [46]. One of the hypotheses has suggested that an increase in SMs in stressed plants is a result of growth inhibition and allocation of fixed carbon into secondary metabolism [46].

$H$. sosnovskyi is well-known for the accumulation of furanocoumarins [47]. Our study showed that both $35^{\circ} \mathrm{C} / 2 \mathrm{~d}$ and $30^{\circ} \mathrm{C} / 7 \mathrm{~d}$ treatments significantly increased the concentration of xanthotoxin (by ca. $80 \%$ ) and bergapten by ca. $60 \%$ and $120 \%$, respectively (Figure 4). Additionally, isopimpinellin was detected only in the heat-exposed plants (Figure $4 \mathrm{~b}$ ). Previous studies showed a stimulating effect of different abiotic stresses, including UV radiation, drought, heavy metals, salinity, air pollution, and biotic stress (insect damage, fungal or bacterial infection) on furanocoumarin content in different plant species ([48] and the references therein). Bourgaud et al. [49] showed that Psoralea cinerea exposed to $32{ }^{\circ} \mathrm{C}$ accumulated three-fold and eight-fold higher levels of angelicin and psoralen, respectively, compared with plants cultivated at $21^{\circ} \mathrm{C}$. Similar findings were reported in Bituminaria bituminosa investigations [48]. The authors reported that higher temperature increased the content of furanocoumarins in roots and leaves of a Calnegre population of B. bituminosa cultivated in hydroponic culture [48]. However, it should be noted that another population, Liano del Beal (population with lower cold sensitivity than Calnegre), did not show changes in furanocoumarin accumulation in response to heat stress [48]. It therefore seems that furanocoumarins are variously regulated by heat stress in the H. sosnovskyi leaves, and further field studies are needed. Quantitative changes of furanocoumarins are also affected by other abiotic stressors, e.g., $\mathrm{SO}_{2}$ excess depletes their content but with various ontogenetic differences [50]. On the contrary, dramatic stimulation of furanocoumarin accumulation occurs after application of some plant hormones such as methyljasmonate or salicylic acid [51], so the role of these metabolites under heat stress remains to be elucidated as an eventual tool for suppression of these dangerous metabolites in Heracleum plants.

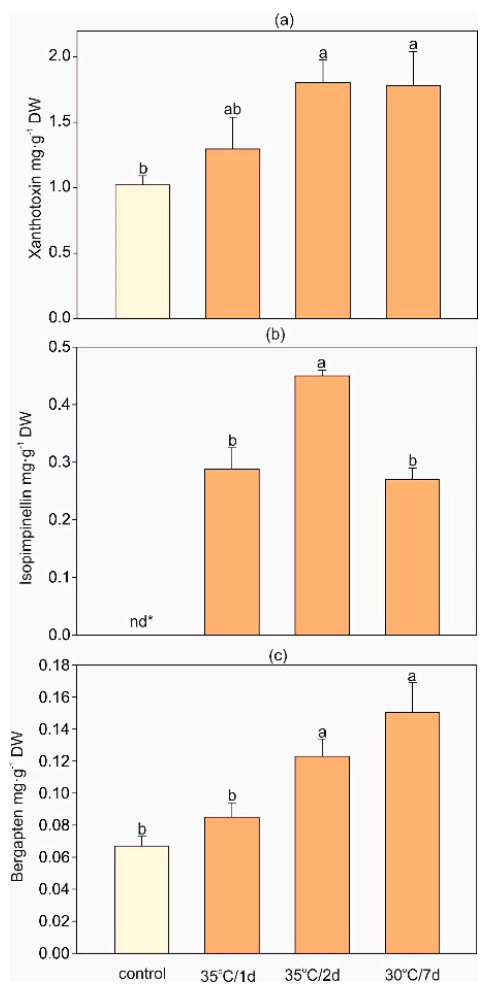

Figure 4. Changes in furanocoumarin contents: (a) xanthotoxin, (b) isopimpinellin, and (c) bergapten in $H$. sosnovskyi in response to stress temperature. Data are means \pm SE $(n=4)$, nd ${ }^{*}$ not detected. Values followed by the same letter(s) are not significantly different according to Tukey's test $(p<0.05)$. 
The short-term heat stress $\left(35^{\circ} \mathrm{C} / 1 \mathrm{~d}\right)$ doubled the content of kaempferol (Figure 5a). This phenomenon was also observed at the level of soluble flavonol content (Table 1). Elevated flavonol amounts in plants exposed to temperature stress were also observed in Solanum lycopersicum [52] or in Vigna angularis [53]. In potatoes (Solanum tuberosum), both short and prolonged heat stress caused the upregulation of precursors of flavone and flavonol biosynthesis [28]. On the contrary to flavonols, the content of chlorogenic acid (Figure 5 b) and soluble phenols decreased in $H$. sosnovskyi under longer treatment $\left(30{ }^{\circ} \mathrm{C} / 7 \mathrm{~d}\right)$, which is in accordance with data from watermelon plants [46]. Both flavonoids and phenolic acids are regarded as efficient antioxidant agents [44]. Here we also found a decrease in antioxidant capacity with the reduction of chlorogenic acid in the leaves exposed to the $30^{\circ} \mathrm{C} / 7 \mathrm{~d}$ treatment (Table 1 ). This finding may suggest that long exposure to high temperature disturbs this nonenzymatic antioxidant system, which was also reflected in the higher oxidative damage described above. In contrast, the $7 \mathrm{~d}$ treatment resulted in an almost 2.5-fold increase in the accumulation of anthocyanins: a significant elevation was also observed in the $35^{\circ} \mathrm{C} / 2 \mathrm{~d}$ treatment (Figure 5c). Previous studies provided ample evidence for the significant effect of temperature stress on the anthocyanin concentration in plant tissues [7]. However, in contrast to our results, earlier reports indicated that elevated temperature decreased the synthesis and stability of these pigments in buds and fruits $[54,55]$. Nevertheless, it should be noted that this phenomenon was observed in nonphotosynthetic organs, while vegetative tissues exposed to heat stress demonstrated a tendency towards the accumulation of anthocyanins [7]. Because anthocyanins participate in a reduction in the leaf osmotic potential, which is directly related to the improvement of water status in plants combined with their antioxidant activities [56], the present results indicate that accumulation of anthocyanins is one of the potential heat stress tolerance mechanisms.
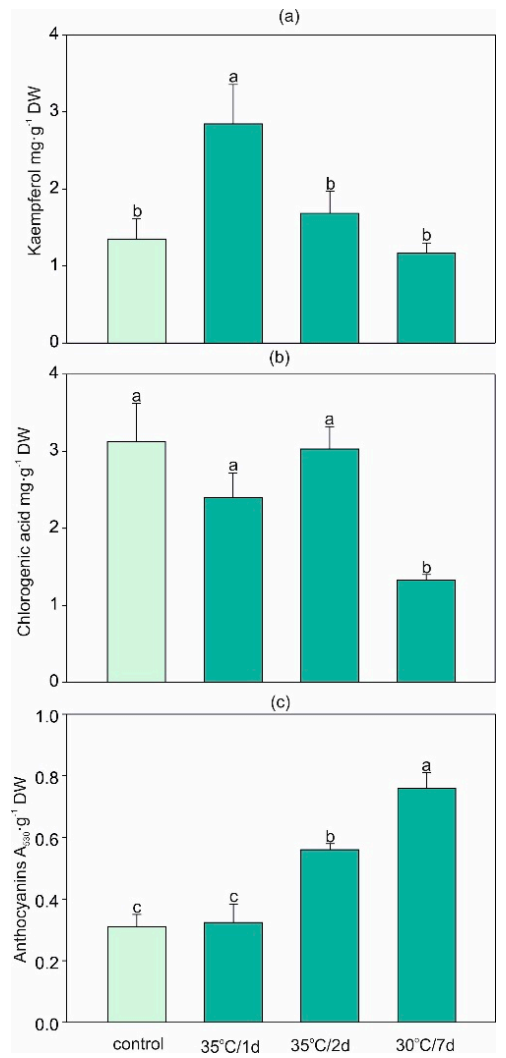

Figure 5. Changes in the contents of selected secondary metabolites (a) kaempferol, (b) chlorogenic acid, and (c) anthocyanins in $H$. sosnovskyi in response to stress temperature. Data are means $\pm \mathrm{SE}$ $(n=4)$. Values followed by the same letter(s) are not significantly different according to Tukey's test $(p<0.05)$. 
Table 1. Effect of high temperature on the content of flavonols and phenols and antioxidant capacity in H. sosnowskyi. Data are means $\pm \mathrm{SE}(n=4)$. Values within the columns followed by the same letter(s) are not significantly different according to Tukey's test $(p<0.05)$.

\begin{tabular}{|c|c|c|c|c|}
\hline & \multirow[t]{2}{*}{$\begin{array}{l}\text { Soluble Flavonols } \\
\left(\mathrm{mg} \text { QUE } \mathrm{g}^{-1} \mathrm{DW}\right)\end{array}$} & \multirow[t]{2}{*}{$\begin{array}{l}\text { Soluble Phenols } \\
\left(\mathrm{mg} \mathrm{GAE} \mathrm{g}^{-1} \mathrm{DW}\right)\end{array}$} & \multicolumn{2}{|c|}{$\begin{array}{l}\text { Antioxidant Capacity } \\
\left(\mathrm{mg} \mathrm{TE}^{-1} \mathrm{DW}\right)\end{array}$} \\
\hline & & & DPPH & ABTS \\
\hline Control & $0.56 \pm 0.04 b$ & $7.97 \pm 1.20 \mathrm{a}$ & $5.08 \pm 0.35 \mathrm{a}$ & $10.31 \pm 0.61 \mathrm{a}$ \\
\hline $35^{\circ} \mathrm{C} / 1 \mathrm{~d}$ & $0.85 \pm 0.12 \mathrm{a}$ & $6.91 \pm 0.72 \mathrm{ab}$ & $2.96 \pm 0.68 \mathrm{~b}$ & $8.45 \pm 0.63 \mathrm{ab}$ \\
\hline $35^{\circ} \mathrm{C} / 2 \mathrm{~d}$ & $0.62 \pm 0.03 b$ & $7.97 \pm 0.54 \mathrm{a}$ & $3.81 \pm 0.26 \mathrm{ab}$ & $9.86 \pm 0.30 \mathrm{a}$ \\
\hline $30^{\circ} \mathrm{C} / 7 \mathrm{~d}$ & $0.52 \pm 0.07 b$ & $5.27 \pm 0.19 \mathrm{~b}$ & $2.64 \pm 0.34 b$ & $7.46 \pm 0.30 \mathrm{~b}$ \\
\hline
\end{tabular}

\subsection{Principle Component Analysis}

Principal component analysis (PCA) of the selected SMs, antioxidant capacity, proline, and lipid peroxidation level (Figure 6) indicated clearly separated groups according to the experimental treatments used. The first component explained almost $48 \%$ of variety total variety, and it was largely determined by all tested variables, except for soluble flavonols and kaempferol. The antioxidant capacity, soluble phenols, and content of chlorogenic acid were positively correlated with PC1, while furanocoumarins, anthocyanins, proline, and lipid peroxidation expressed as thiobarbituric-acid-reactive substances (TBARS) were negatively correlated with PC1. PC1 facilitated the separation of the control from the long-term heat stress individuals, with the latter characterized by a higher accumulation of furanocoumarins, anthocyanins, and proline and a higher level of lipid peroxidation. In turn, the nonstressed plants contained higher levels of antioxidant compounds, including soluble phenols and chlorogenic acid. Plants exposed to both the $1 \mathrm{~d}$ and $2 \mathrm{~d}$ stress $\left(35^{\circ} \mathrm{C}\right)$ exhibited intermediate values of the analyzed parameters in comparison to control and $7 \mathrm{~d}$ stress. However, the plants in the $35^{\circ} \mathrm{C} / 1 \mathrm{~d}$ treatment were slightly influenced by the PC2 factor and were positively correlated with soluble flavonols and kaempferol.

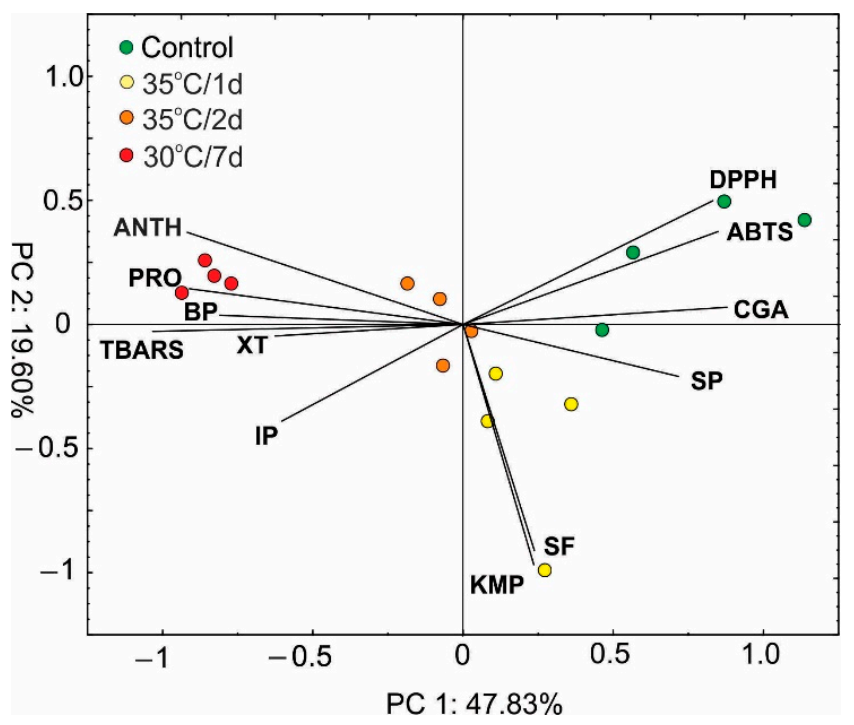

Figure 6. Scaled scatter plot of the principal component analysis of selected secondary metabolites, antioxidant capacity, proline, and the lipid peroxidation level (ANTH—anthocyanins; antioxidant capacity (ABTS, DPPH), BP—bergapten; CGA—chlorogenic acid; IP—isopimpinellin; KMP—kaempferol; $\mathrm{PRO}$ - proline; SP—soluble phenols; SF-soluble flavonols; TBARS—-thiobarbituric acid reactive substances; XT-xanthotoxin). The length of the lines shows a correlation between original data and the factor axes. 


\section{Materials and Methods}

\subsection{Plant Materials and Experimental Design}

Mature fruits of $H$. sosnowskyi were sampled in the Lublin city area in September 2019. Seeds were collected from 10 randomly selected plants. The collected seeds showed a similar degree of ripeness, as indicated by their color and hardness. To break seed dormancy, cold stratification pretreatments at $0^{\circ} \mathrm{C}$ on glass Petri dishes in moisture vermiculite were applied for ten weeks. After conditioning, five replicates of 15 seeds were sown on the surface of moist vermiculite and incubated simulating a day/night cycle $(12 \mathrm{~h}$ light $/ 12 \mathrm{~h}$ dark) under a temperature regime $\left(22 / 15^{\circ} \mathrm{C}\right)$ and humidity $60 \%$ for 30 days in a growth chamber. When they formed the first leaf, the seedlings were transferred into pots (one plant per pot) filled with garden soil. Cultivation was carried out in a growth chamber at $18 / 25^{\circ} \mathrm{C}(8 / 16 \mathrm{~h}$ dark/light photoperiod) under light-emitting diodes at a photosynthetic photon flux density of $150 \mu \mathrm{mol} \mathrm{m}{ }^{-2} \mathrm{~s}^{-1}$ and relative humidity of $60-65 \%$ for 60 days. When 3-4 mature leaves were formed, the plants were divided into three groups (10 plants per treatment): the control $\left(18 / 25^{\circ} \mathrm{C}, 7\right.$ days), short-term temperature stress in two variants: A $\left(18 / 25^{\circ} \mathrm{C}, 6\right.$ days followed by 1 day with $\left.28 / 35^{\circ} \mathrm{C}\right)$ and $\mathrm{B}\left(18 / 25^{\circ} \mathrm{C}, 5\right.$ days followed by 2 days with $\left.28 / 35^{\circ} \mathrm{C}\right)$, and longer heat stress $\left(23 / 30^{\circ} \mathrm{C}, 7\right.$ days). Preliminary experiment showed that plants did not grow well at $35^{\circ} \mathrm{C} / 7 \mathrm{~d}$, then temperature $30^{\circ} \mathrm{C}$ was tested for longer exposure. During the cultivation, plants were watered to maintain constant soil moisture. For metabolic analyses, leaves from one plant were powdered in liquid nitrogen to make aliquots for subsequent analyses. Four individual plants were analyzed for each parameter.

\subsection{Photosynthetic Pigment Content and Chlorophyll Fluorescence Measurement}

The leaves samples were homogenized in $80 \%$ acetone and centrifuged, and the content of chlorophyll a, b, and carotenoids was measured spectrophotometrically (UV160A Shimadzu, Tokyo, Japan) and calculated according to Wellburn [57].

Chlorophyll a fluorescence measurement belongs to noninvasive and highly speciesspecific techniques used to assess the photosynthetic performance of plants [36,58]. The parameter was measured using Closed FluorCam FC 800-C (Photon Systems Instruments, Brno, Czech Republic). Exactly before the measurement, parts of the leaf were dark-adapted for $30 \mathrm{~min}$ to relax the reaction centers. The following parameters were established: minimal fluorescence in the dark-adapted state (F0), maximal fluorescence in the dark-adapted state $(\mathrm{Fm})$, maximum quantum yield of PSII in the dark-adapted state $(\mathrm{Fv} / \mathrm{Fm})$, photochemical quenching of fluorescence (qP), nonphotochemical quenching of fluorescence (qN), and the ratio of fluorescence decrease ( $\mathrm{Rfd})$.

\subsection{Detection of $\mathrm{H}_{2} \mathrm{O}_{2}$ and Determination of Lipid Peroxidation and Free Proline Accumulation}

The visualization of hydrogen peroxide $\left(\mathrm{H}_{2} \mathrm{O}_{2}\right)$ in the $H$. sosnovskyi leaves was performed using 3',3-diamionobenzidine (DAB) according to the method of [14].

The level of lipid peroxidation was estimated based on the content of thiobarbituricacid-reactive substances (TBARS) according to the method described previously [59].

The free proline concentration was determined spectrophotometrically as described before [60].

\subsection{Determination of Secondary Metabolites and Antioxidant Capacity}

The Heracleum leaf samples were air-dried and ground into fine powder. In total, $0.25 \mathrm{~g}$ of air-dried material was extracted three times with $80 \%$ methanol $(2 \times 2 \mathrm{~mL})$ in an ultrasonic bath (Sonorex Digitec DT100/H, Bandelin, Berlin, Germany) for $30 \mathrm{~min}$. The extracts were centrifuged (Eppendorf 5804 R, Hamburg, Germany) at $4500 \times g$ for 5 min. Prior to the analysis of metabolites, the supernatants were filtered through $0.22 \mu \mathrm{m}$ nylon filters (Kinesis, Cambridgeshire, UK).

Measurement of the furanocoumarin content was conducted using an Agilent 7100 capillary electrophoresis system equipped with a diode-array detector (Agilent Technolo- 
gies, Santa Clara, CA, USA) according to the method described previously [61]. Briefly, a fused-silica capillary (50 $\mu \mathrm{m}$ i.d. and $64.5 \mathrm{~cm}$ total length) (Agilent Technologies, Santa Clara, CA, USA) was used for the analysis. The separation was performed in $50 \mathrm{mM}$ sodium tetraborate buffer containing $65 \mathrm{mM}$ sodium cholate and $20 \%$ methanol.

The content of chlorogenic acid was measured using an RP18e LiChrospher 100 column (Merck, Darmstadt, Germany) $(25 \mathrm{~cm} \times 4.0 \mathrm{~mm}$ i.d., $5 \mu \mathrm{m}$ particle size) according to the procedure published previously [62].

Before kaempferol measurements, the methanolic extract was hydrolyzed at $80{ }^{\circ} \mathrm{C}$ for 120 min using $6 \mathrm{M} \mathrm{HCl}$. After acid neutralization with a $25 \%$ ammonium solution, the mixture was dried and dissolved in water. Prior to HPLC measurements, the solution was purified using solid-phase extraction columns (Lichrolut RP-18, Merck, Darmstadt, Germany). HPLC analysis of kaempferol was performed using a Kinetex C18 reverse-phase column $(10 \mathrm{~cm} \times 4.0 \mathrm{~mm}$ i.d., $2.6 \mu \mathrm{m}$ particle size) (Phenomenex, Torrance, CA, USA) according to a method described previously [63]. HPLC measurements of both kaempferol and chlorogenic acid were performed using a VWR Hitachi Chromaster 600 chromatograph equipped with a UV-Vis DAD detector (Merck, Darmstadt, Germany).

The quantification of metabolites was performed from calibration curves prepared with standard compounds (Sigma-Aldrich, St. Louis, MO, USA).

The total concentration of anthocyanins was determined colorimetrically after extraction with acidified methanol $(1 \% \mathrm{HCl}, v / v)$. The total anthocyanin amount was expressed as absorbance unit corrected by chlorophyll contribution $\left(\mathrm{A}_{530}-0.25 \times \mathrm{A}_{657}\right)$ as described before [64,65].

Soluble flavonol content expressed as mg of quercetin equivalent per gram of dry weight matter was measured based on the formation of a flavonol-aluminum complex [66]. Folin-Ciocalteu reagent was used to analyze soluble phenols, and the contents were expressed as gallic acid equivalents per gram of dry weight matter [67]. Trolox equivalent per gram of dry matter was used to express the antioxidant capacity measured with the use of two types of free radicals: 2-azino-bis-3-ethylbenzthiazoline-6-sulphonic acid (ABTS) and 2,2-diphenyl-1-picrylhydrazyl (DPPH) [68].

In parallel, the residual water content of air-dried samples of Heracleum leaves was determined after drying in an oven at $90^{\circ} \mathrm{C}$ for $12 \mathrm{~h}$ and all data were recalculated per gram of absolute dry weight.

\subsection{Statistical Analysis}

At least 4 individual pots with 1 plant per pot were cultured for each treatment. The experiment was independently repeated 2 times in the same growth conditions. The results were analyzed using a one-way analysis of variance. Before, the normality assumption and homogeneity of variance were checked using Shapiro-Wilk's test and Levene's test, respectively. The significant differences between the treatments were estimated with Tukey's test $(p<0.05)$. The principal component analyses (PCA) were carried out separately for biochemical and photosynthetic parameters (Supplementary Materials Figure S4). Statistica ver. 13.3 (TIBCO Software Inc. 2017, Palo Alto, CA, USA) was used to perform all statistical analyses.

\section{Conclusions}

The results showed that both short-term and longer heat stress altered the accumulation of SMs in H. sosnowskyi. A strong correlation between high temperature stress and furanocoumarin content in the leaves was found. This phenomenon was more noticeable in the $35^{\circ} \mathrm{C} / 2 \mathrm{~d}$ and $30^{\circ} \mathrm{C} / 7 \mathrm{~d}$ treatments. Interestingly, the accumulation of isopimpinellin was observed only in stressed plants. The study also showed that the accumulation of osmolytes, i.e., proline and anthocyanins, could be one of the mechanisms of heat tolerance in H. sosnowskyi. Even short stress $\left(35^{\circ} \mathrm{C} / 1 \mathrm{~d}\right)$ caused a significantly higher decrease in the maximum chlorophyll and photosynthetic yield compared with the other stress treatments. 
In turn, the lipid peroxidation or $\mathrm{H}_{2} \mathrm{O}_{2}$ accumulation was much more elevated by longer stress as naturally expected.

Supplementary Materials: The following are available online at https:/ /www.mdpi.com/article/10 .3390/ijms22094756/s1.

Author Contributions: A.R., S.D., A.H. and B.H.-N. designed the project; A.R. and S.D. cultivation of the plants, A.R. and A.H. photosynthesis, M.S. and M.W. HPLC analysis; A.R. and S.D. analysis of furanocoumarins, $\mathrm{SF}, \mathrm{SP}$, and antioxidants; B.H.-N. analysis of proline, TBRAS, $\mathrm{H}_{2} \mathrm{O}_{2}$ visualization A.R., S.D., A.H. and B.H.-N. prepared the original manuscript draft; A.R. and S.D. statistical analysis and data visualization; M.L. and I.S. funding; J.K. was involved in experimental ideas and critically revised the manuscript. All authors have read and agreed to the published version of the manuscript.

Funding: This research received no external funding.

Institutional Review Board Statement: Not applicable.

Informed Consent Statement: Not applicable.

Data Availability Statement: The data presented in this study are available on request from the corresponding authors.

Conflicts of Interest: The authors declare no conflict of interest.

\section{References}

1. Sala, O.E.; Chapin, F.S.; Armesto, J.J.; Berlow, E.; Bloomfield, J.; Dirzo, R.; Huber-Sanwald, E.; Huenneke, L.F.; Jackson, R.B.; Kinzig, A.; et al. Global Biodiversity Scenarios for the Year 2100. Science 2000, 287, 1770-1774. [CrossRef]

2. Byers, J.E. Impact of Non-Indigenous Species on Natives Enhanced by Anthropogenic Alteration of Selection Regimes. Oikos 2002, 97, 449-458. [CrossRef]

3. Crowl, T.A.; Crist, T.O.; Parmenter, R.R.; Belovsky, G.; Lugo, A.E. The Spread of Invasive Species and Infectious Disease as Drivers of Ecosystem Change. Front. Ecol. Environ. 2008, 6, 238-246. [CrossRef]

4. Somero, G.N. The Physiology of Climate Change: How Potentials for Acclimatization and Genetic Adaptation Will Determine 'Winners' and 'Losers'. J. Exp. Biol. 2010, 213, 912-920. [CrossRef]

5. Somero, G.N. The Physiology of Global Change: Linking Patterns to Mechanisms. Ann. Rev. Mar. Sci. 2012, 4, 39-61. [CrossRef] [PubMed]

6. Karmalkar, A.V.; Bradley, R.S. Consequences of Global Warming of $1.5^{\circ} \mathrm{C}$ and $2{ }^{\circ} \mathrm{C}$ for Regional Temperature and Precipitation Changes in the Contiguous United States. PLoS ONE 2017, 12, e0168697. [CrossRef]

7. Wahid, A.; Gelani, S.; Ashraf, M.; Foolad, M.R. Heat Tolerance in Plants: An Overview. Environ. Exp. Bot. 2007, 61, 199-223. [CrossRef]

8. Hasanuzzaman, M.; Nahar, K.; Alam, M.; Roychowdhury, R.; Fujita, M. Physiological, Biochemical, and Molecular Mechanisms of Heat Stress Tolerance in Plants. Int. J. Mol. Sci. 2013, 14, 9643-9684. [CrossRef]

9. Zobayed, S.M.A.; Afreen, F.; Kozai, T. Temperature Stress Can Alter the Photosynthetic Efficiency and Secondary Metabolite Concentrations in St. John's Wort. Plant Physiol. Biochem. 2005, 43, 977-984. [CrossRef]

10. Liu, Y.; Lin-Wang, K.; Espley, R.V.; Wang, L.; Li, Y.; Liu, Z.; Zhou, P.; Zeng, L.; Zhang, X.; Zhang, J.; et al. StMYB44 Negatively Regulates Anthocyanin Biosynthesis at High Temperatures in Tuber Flesh of Potato. J. Exp. Bot. 2019, 70, 3809-3824. [CrossRef]

11. Weryszko-Chmielewska, E.; Chwil, M. Structures of Heracleum Sosnovskii Manden. Stem and Leaves Releasing PhotodermatosisCausing Substances. Acta Agrobot. 2012, 67, 25-32. [CrossRef]

12. Balal, R.M.; Shahid, M.A.; Javaid, M.M.; Iqbal, Z.; Anjum, M.A.; Garcia-Sanchez, F.; Mattson, N.S. The Role of Selenium in Amelioration of Heat-Induced Oxidative Damage in Cucumber under High Temperature Stress. Acta Physiol. Plant 2016, 38, 158. [CrossRef]

13. Alhaithloul, H.A.S. Impact of Combined Heat and Drought Stress on the Potential Growth Responses of the Desert Grass Artemisia Sieberi Alba: Relation to Biochemical and Molecular Adaptation. Plants 2019, 8, 416. [CrossRef]

14. Hawrylak-Nowak, B.; Dresler, S.; Rubinowska, K.; Matraszek-Gawron, R.; Woch, W.; Hasanuzzaman, M. Selenium Biofortification Enhances the Growth and Alters the Physiological Response of Lamb's Lettuce Grown under High Temperature Stress. Plant Physiol. Bioch. 2018, 127, 446-456. [CrossRef]

15. Efeoglu, B.; Terzioglu, S. Photosynthetic Responses of Two Wheat Varieties to High Temperature. Eurasian J. Biosci. 2009, 3, 97-106. [CrossRef]

16. Yamane, Y.; Shikanai, T.; Kashino, Y.; Koike, H.; Satoh, K. Reduction of QA in the Dark: Another Cause of Fluorescence Fo Increases by High Temperatures in Higher Plants. Photosynth. Res. 2000, 63, 23-34. [CrossRef] [PubMed]

17. Haldimann, P.; Feller, U. Inhibition of Photosynthesis by High Temperature in Oak (Quercus Pubescens L.) Leaves Grown under Natural Conditions Closely Correlates with a Reversible Heat-Dependent Reduction of the Activation State of Ribulose-1,5Bisphosphate Carboxylase/Oxygenase. Plant Cell Environ. 2004, 27, 1169-1183. [CrossRef] 
18. Allakhverdiev, S.; Kreslavskii, V.; Klimov, V.; Los, D.; Carpentier, R.; Mohanty, P. Heat Stress: An Overview of Molecular Responses in Photosynthesis. Photosynth. Res. 2008, 98, 541-550. [CrossRef]

19. Srivastava, A.; Guissé, B.; Greppin, H.; Strasser, R.J. Regulation of Antenna Structure and Electron Transport in Photosystem II of Pisum Sativum under Elevated Temperature Probed by the Fast Polyphasic Chlorophyll a Fluorescence Transient: OKJIP. Biochim. Biophys. Acta Bioenerg. 1997, 1320, 95-106. [CrossRef]

20. Berry, J.; Bjorkman, O. Photosynthetic Response and Adaptation to Temperature in Higher Plants. Annu. Rev. Plant Physiol. 1980, 31, 491-543. [CrossRef]

21. Reszczyńska, E.; Hanaka, A. Lipids Composition in Plant Membranes. Cell Biochem. Biophys. 2020, 78, 401-414. [CrossRef] [PubMed]

22. Pastenes, C.; Horton, P. Effect of High Temperature on Photosynthesis in Beans (I. Oxygen Evolution and Chlorophyll Fluorescence). Plant Physiol. 1996, 112, 1245-1251. [CrossRef] [PubMed]

23. Mathur, S.; Agrawal, D.; Jajoo, A. Photosynthesis: Response to High Temperature Stress. J. Photochem. Photobiol. B Biol. 2014, 137, 116-126. [CrossRef]

24. Yang, X.; Wen, X.; Gong, H.; Lu, Q.; Yang, Z.; Tang, Y.; Liang, Z.; Lu, C. Genetic Engineering of the Biosynthesis of Glycinebetaine Enhances Thermotolerance of Photosystem II in Tobacco Plants. Planta 2007, 225, 719-733. [CrossRef]

25. Kreslavskii, V.; Zorina, A.; Los, D.; Fomina, I.; Allakhverdiev, S. Molecular Mechanisms of Stress Resistance of Photosynthetic Machinery. In Molecular Stress Physiology of Plants; Springer: New Delhi, India, 2013; pp. 21-51, ISBN 978-81-322-0806-8.

26. Aminaka, R.; Taira, Y.; Kashino, Y.; Koike, H.; Satoh, K. Acclimation to the Growth Temperature and Thermosensitivity of Photosystem II in a Mesophilic Cyanobacterium, Synechocystis Sp. PCC6803. Plant Cell Physiol. 2006, 47, 1612-1621. [CrossRef]

27. Guidi, L.; Lo Piccolo, E.; Landi, M. Chlorophyll Fluorescence, Photoinhibition and Abiotic Stress: Does It Make Any Difference the Fact to Be a C3 or C4 Species? Front. Plant Sci. 2019, 10, 174. [CrossRef] [PubMed]

28. Liu, B.; Kong, L.; Zhang, Y.; Liao, Y. Gene and Metabolite Integration Analysis through Transcriptome and Metabolome Brings New Insight into Heat Stress Tolerance in Potato (Solanum Tuberosum L.). Plants 2021, 10, 103. [CrossRef]

29. Roháček, K. Chlorophyll Fluorescence Parameters: The Definitions, Photosynthetic Meaning, and Mutual Relationships. Photosynthetica 2002, 40, 13-29. [CrossRef]

30. Xu, Q.; Ma, X.; Lv, T.; Bai, M.; Wang, Z.; Niu, J. Effects of Water Stress on Fluorescence Parameters and Photosynthetic Characteristics of Drip Irrigation in Rice. Water 2020, 12, 289. [CrossRef]

31. de Melo, H.F.; de Souza, E.R.; Cunha, J.C.; de Melo, H.F.; de Souza, E.R.; Cunha, J.C. Fluorescence of Chlorophyll a and Photosynthetic Pigments in Atriplex Nummularia under Abiotic Stresses. Rev. Bras. Eng. Agrícola Ambient. 2017, 21, $232-237$. [CrossRef]

32. Baker, N.R. Chlorophyll Fluorescence: A Probe of Photosynthesis In Vivo. Annu. Rev. Plant Biol. 2008, 59, 89-113. [CrossRef]

33. Li, G.; Wan, S.; Zhou, J.; Yang, Z.; Qin, P. Leaf Chlorophyll Fluorescence, Hyperspectral Reflectance, Pigments Content, Malondialdehyde and Proline Accumulation Responses of Castor Bean (Ricinus Communis L.) Seedlings to Salt Stress Levels. Ind. Crop. Prod. 2010, 31, 13-19. [CrossRef]

34. Yamada, M.; Hidaka, T.; Fukamachi, H. Heat Tolerance in Leaves of Tropical Fruit Crops as Measured by Chlorophyll Fluorescence. Sci. Hortic. 1996, 67, 39-48. [CrossRef]

35. Rahimzadeh-Bajgiran, P.; Tubuxin, B.; Omasa, K. Estimating Chlorophyll Fluorescence Parameters Using the Joint Fraunhofer Line Depth and Laser-Induced Saturation Pulse (FLD-LISP) Method in Different Plant Species. Remote Sens. 2017, 9, 599. [CrossRef]

36. Maxwell, K.; Johnson, G.N. Chlorophyll Fluorescence-A Practical Guide. J. Exp. Bot. 2000, 51, 659-668. [CrossRef] [PubMed]

37. Xu, S.; Li, J.; Zhang, X.; Wei, H.; Cui, L. Effects of Heat Acclimation Pretreatment on Changes of Membrane Lipid Peroxidation, Antioxidant Metabolites, and Ultrastructure of Chloroplasts in Two Cool-Season Turfgrass Species under Heat Stress. Environ. Exp. Bot. 2006, 56, 274-285. [CrossRef]

38. Liu, X.; Huang, B. Heat Stress Injury in Relation to Membrane Lipid Peroxidation in Creeping Bentgrass. Crop. Sci. 2000, 40, 503-510. [CrossRef]

39. Jiang, Y.; Huang, B. Drought and Heat Stress Injury to Two Cool-Season Turfgrasses in Relation to Antioxidant Metabolism and Lipid Peroxidation. Crop. Sci. 2001, 41, 436-442. [CrossRef]

40. Gong, M.; Li, Y.-J.; Dai, X.; Tian, M.; Li, Z.-G. Involvement of Calcium and Calmodulin in the Acquisition of Heat-Shock Induced Thermotolerance in Maize Seedlings. J. Plant Physiol. 1997, 150, 615-621. [CrossRef]

41. Rizhsky, L.; Liang, H.; Shuman, J.; Shulaev, V.; Davletova, S.; Mittler, R. When Defense Pathways Collide. The Response of Arabidopsis to a Combination of Drought and Heat Stress. Plant Physiol. 2004, 134, 1683-1696. [CrossRef]

42. Harsh, A.; Sharma, Y.K.; Joshi, U.; Rampuria, S.; Singh, G.; Kumar, S.; Sharma, R. Effect of Short-Term Heat Stress on Total Sugars, Proline and Some Antioxidant Enzymes in Moth Bean (Vigna Aconitifolia). Ann. Agric. Sci. 2016, 61, 57-64. [CrossRef]

43. Gall, H.L.; Philippe, F.; Domon, J.-M.; Gillet, F.; Pelloux, J.; Rayon, C. Cell Wall Metabolism in Response to Abiotic Stress. Plants 2015, 4, 112-166. [CrossRef]

44. Dresler, S.; Wójciak-Kosior, M.; Sowa, I.; Stanisławski, G.; Bany, I.; Wójcik, M. Effect of Short-Term Zn/Pb or Long-Term Multi-Metal Stress on Physiological and Morphological Parameters of Metallicolous and Nonmetallicolous Echium Vulgare L. Populations. Plant Physiol. Bioch. 2017, 115, 380-389. [CrossRef] [PubMed]

45. Ramakrishna, A.; Ravishankar, G.A. Influence of Abiotic Stress Signals on Secondary Metabolites in Plants. Plant Signal Behav. 2011, 6, 1720-1731. [CrossRef] [PubMed] 
46. Rivero, R.M.; Ruiz, J.M.; García, P.C.; López-Lefebre, L.R.; Sánchez, E.; Romero, L. Resistance to Cold and Heat Stress: Accumulation of Phenolic Compounds in Tomato and Watermelon Plants. Plant Sci. 2001, 160, 315-321. [CrossRef]

47. Bogucka-Kocka, A.; Krzaczek, T. The Furanocoumarins in the Roots of Heracleum Sibiricum L. Acta Pol. Pharm. Drug Res. 2003, 60, 391-393.

48. Walker, D.J.; Martínez-Fernández, D.; Correal, E.; Romero-Espinar, P.; Antonio del Río, J. Accumulation of Furanocoumarins by Bituminaria Bituminosa in Relation to Plant Development and Environmental Stress. Plant Physiol. Biochem. 2012, 54, 133-139. [CrossRef]

49. Bourgaud, F.; Brunel, M.C.; Guckert, A.; Forlot, P. Effect of Nitrogen Nutrition and Environmental Conditions on the Production of Pharmaceutically Useful Metabolites by Psoralea Cinerea. Eur. J. Agron. 1992, 1, 37-43. [CrossRef]

50. Ali, S.T.; Mahmooduzzafar, M.Z.; Iqbal, M. Ontogenetic Changes in Foliar Features and Psoralen Content of Psoralea Corylifolia Linn. Exposed to $\mathrm{SO}_{2}$ Stress. J. Environ. Biol. 2008, 29, 661-668.

51. Cai, J.; Ma, Y.; Hu, P.; Zhang, Y.; Chen, J.; Li, X. Elicitation of Furanocoumarins in Changium Smyrnioides Suspension Cells. Plant Cell Tissue Organ Cult. 2017, 130, 1-12. [CrossRef]

52. Martinez, V.; Mestre, T.C.; Rubio, F.; Girones-Vilaplana, A.; Moreno, D.A.; Mittler, R.; Rivero, R.M. Accumulation of Flavonols over Hydroxycinnamic Acids Favors Oxidative Damage Protection under Abiotic Stress. Front. Plant Sci. 2016, 7, 838. [CrossRef] [PubMed]

53. Złotek, U.; Szymanowska, U.; Baraniak, B.; Karaś, M. Antioxidant Activity of Polyphenols of Adzuki Bean (Vigna Angularis) Germinated in Abiotic Stress Conditions. Acta Sci. Pol. Technol. Aliment. 2015, 14, 55-63. [CrossRef] [PubMed]

54. Shvarts, M.; Borochov, A.; Weiss, D. Low Temperature Enhances Petunia Flower Pigmentation and Induced Chalcone Synthase Gene Expression. Physiol. Plant. 1997, 99, 67-72. [CrossRef]

55. Shaked-Sachray, L.; Weiss, D.; Reuveni, M.; Nissim-Levi, A.; Oren-Shamir, M. Increased Anthocyanin Accumulation in Aster Flowers at Elevated Temperatures Due to Magnesium Treatment. Physiol. Plant. 2002, 114, 559-565. [CrossRef] [PubMed]

56. Chalker-Scott, L. Do Anthocyanins Function as Osmoregulators in Leaf Tissues? In Advances in Botanical Research; Academic Press: Amsterdam, The Netherlands, 2002; Volume 37, pp. 103-127.

57. Wellburn, A.R. The Spectral Determination of Chlorophylls a and b, as Well as Total Carotenoids, Using Various Solvents with Spectrophotometers of Different Resolution. J. Plant Physiol. 1994, 144, 307-313. [CrossRef]

58. Hanaka, A.; Maksymiec, W.; Bednarek, W. The Effect of Methyl Jasmonate on Selected Physiological Parameters of Copper-Treated Phaseolus Coccineus Plants. Plant Growth Regul. 2015, 77, 167-177. [CrossRef]

59. Hawrylak-Nowak, B. Comparative effects of selenite and selenate on growth and selenium accumulation in lettuce plants under hydroponic conditions. Plant Growth Regul. 2013, 70, 149-157. [CrossRef]

60. Bates, L.S.; Waldren, R.P.; Teare, I.D. Rapid determination of free proline for water-stress studies. Plant Soil 1973, 39, $205-207$. [CrossRef]

61. Dresler, S.; Bogucka-Kocka, A.; Kováčik, J.; Kubrak, T.; Strzemski, M.; Wójciak-Kosior, M.; Rysiak, A.; Sowa, I. Separation and Determination of Coumarins Including Furanocoumarins Using Micellar Electrokinetic Capillary Chromatography. Talanta 2018, 187, 120-124. [CrossRef]

62. Strzemski, M.; Płachno, B.J.; Mazurek, B.; Kozłowska, W.; Sowa, I.; Lustofin, K.; Załuski, D.; Rydzik, Ł.; Szczepanek, D.; Sawicki, J.; et al. Morphological, Anatomical, and Phytochemical Studies of Carlina Acaulis L. Cypsela. Int. J. Mol. Sci. 2020, $21,9230$. [CrossRef]

63. Dresler, S.; Strzemski, M.; Kováčik, J.; Sawicki, J.; Staniak, M.; Wójciak, M.; Sowa, I.; Hawrylak-Nowak, B. Tolerance of Facultative Metallophyte Carlina Acaulis to Cadmium Relies on Chelating and Antioxidative Metabolites. Int. J. Mol. Sci. 2020, $21,2828$. [CrossRef] [PubMed]

64. Dresler, S.; Bednarek, W.; Wójcik, M. Effect of Cadmium on Selected Physiological and Morphological Parameters in Metallicolous and Non-Metallicolous Populations of Echium Vulgare L. Ecotoxicol. Environ. Saf. 2014, 104, 332-338. [CrossRef] [PubMed]

65. Mancinelli, A.L.; Yang, C.-P.H.; Lindquist, P.; Anderson, O.R.; Rabino, I. Photocontrol of Anthocyanin Synthesis: III. The Action of Streptomycin on the Synthesis of Chlorophyll and Anthocyanin 1. Plant Physiol. 1975, 55, 251-257. [CrossRef]

66. Deng, H.; Berkel, G.J.V. Electrospray Mass Spectrometry and UV/Visible Spectrophotometry Studies of Aluminum(III)-Flavonoid Complexes. J. Mass Spectrom. 1998, 33, 1080-1087. [CrossRef]

67. Kováčik, J.; Bačkor, M.; Kaduková, J. Physiological Responses of Matricaria Chamomilla to Cadmium and Copper Excess. Environ. Toxicol. 2008, 23, 123-130. [CrossRef]

68. Dresler, S.; Rutkowska, E.; Bednarek, W.; Stanisławski, G.; Kubrak, T.; Bogucka-Kocka, A.; Wójcik, M. Selected Secondary Metabolites in Echium Vulgare L. Populations from Nonmetalliferous and Metalliferous Areas. Phytochemistry 2017, 133, 4-14. [CrossRef] 